\title{
CHEMOSPHERE
}

\section{The surface characteristics of activated carbon as affected by ozone and alkaline treatment}

\author{
Hung-Lung Chiang ${ }^{\text {a }}$, C.P. Huang ${ }^{\text {b,* }}$, P.C. Chiang ${ }^{c}$ \\ ${ }^{a}$ Department of Environmental Engineering, Fooyin Institute of Technology, Kaohsiung Hsien, 831, Taiwan, ROC \\ ${ }^{\mathrm{b}}$ Department of Civil and Environmental Engineering, University of Delaware, Newark, DE 19716, USA \\ ${ }^{\mathrm{c}}$ Graduate Institute of Environmental Engineering, National Taiwan University, Taipei, Taiwan, ROC
}

Received 17 April 2000; received in revised form 6 July 2001; accepted 13 August 2001

\begin{abstract}
The surface chemical characteristics of activated carbon treated by ozone and alkaline are determined in terms of surface functional groups and surface acidity. Surface functional groups are analyzed by the IR spectroscopic method and Boehm's titration technique. The surface acidity of activated carbon is determined by electrophoretic mobility measurements. The oxygen concentration of activated carbon increases upon ozone and $\mathrm{NaOH}$ treatment. Surface functional groups increase mostly in the hydroxyl and carboxyl categories rather than the carbonyl category upon ozone and $\mathrm{NaOH}$ treatment. (c) 2002 Elsevier Science Ltd. All rights reserved.
\end{abstract}

Keywords: Activated carbon; Ozone; Alkaline; Oxygen concentration; Surface functional groups

\section{Introduction}

Activated carbon can be produced from a great variety of carbonaceous materials including coconut shells, sawdust, wood char, coal, petroleum coke, bone char, molasses, peat and paper-mill waste (lignin) (Mattson and Mark, 1971; Hassler, 1974; Bansal et al., 1990). Depending on the extent of oxidation reaction, two types of activated carbon can be produced (Mattson and Mark, 1971; Hassler, 1974; Corapcioglu and Huang, 1987; Bansal et al., 1990): H-type and L-type. H-type activated carbons exhibit positive charge in water, adsorb strong acid and are hydrophobic. L-type activated carbons display negative charge in water, neutralize strong bases and are hydrophilic. Much has been reported on the oxidation of activated carbon. Steebberg (1944) characterized the activation and oxidation of

\footnotetext{
* Corresponding author. Tel.: +1-302-831-8428; fax: +1-302831-3640.

E-mail address: huang@mail.ce.udel.edu (C.P. Huang).
}

carbon at various temperatures and classified those carbons that were oxidized at low-temperature and adsorbed primarily hydroxide ion as L-carbons, and those activated at high temperatures and adsorbed strong acid as $\mathrm{H}$-carbons. The L-carbon behavior is expected to intensify after long exposure to the atmosphere even at ambient temperatures. Cookson (1978) and Huang (1978) reported the adsorption of electrolytes and nonelectrolytes and its effect on the structure of the electrical double layer and the role of surface functional group on the nature of adsorption.

Bailey (1982) proposed two mechanistic extremes for the oxidation of carbon by ozone: a radical type, ozone-initiated autoxidation, and a concerted reaction, i.e., 1, 3-dipolat insertion. Schubert and Pease (1956a) reported that in the high temperature range, molecular oxygen participates in the reaction as the temperature increases up to $270{ }^{\circ} \mathrm{C}$. The reaction then becomes a slow combustion process that is indistinguishable from the reaction with oxygen alone. At low temperature, the mechanism of vapor-phase reaction is similar to that of liquid-phase ozonation, at least when only molecular 
ozone is involved. At ordinary temperature, reactions in general occur via an ozone insertion mechanism involving the hydrotrioxide $\left(\mathrm{RO}_{3}^{\bullet}\right)$ intermediate, its product, peroxides $\left(\mathrm{RO}_{2}^{\bullet}\right)$ and other radicals. If ozone is the principal reactant, no chain reaction will take place. In the presence of metal catalysts, radical chain mechanisms are involved and become an important part of the oxidation reaction.

Reaction between activated carbon and alkaline is another chemical means for the modification of surface property. Under alkaline environment, it is expected that $\mathrm{OH}^{-}$will react with the surface functional groups of the activated carbon. However, little is available in the literature on the effect of alkaline and ozone treatment on the surface property changes of activated carbon. The objective of this study was to evaluate the surface property changes of an activated carbon upon treatment by ozone and alkaline. Infrared spectroscopy, electrophoretic measurements and alkalimetric titration were used to assess the changes of surface property of the activated carbon.

\section{Experimental}

\subsection{Material}

An activated carbon $(8 \times 30$ mesh $)$, made from coconut shells and provided by Kowa Cosmos Company, Japan was used in this study. Prior to chemical treatment, the surface property of this activated carbon was characterized. Detailed experimental procedures for the characterization of surface property were reported elsewhere (Chiang et al., 1999). This activated carbon has a BET surface area, average pore diameter, macropore volume (>500 ̊), mesopore volume (between 20 and $500 \AA)$, and macropore volume $(<20 \AA)$ of $795 \pm 50$ $\mathrm{m}^{2} / \mathrm{g}, \quad 14.7 \pm 0.05 \AA, \quad 0.011 \pm 0.009 \mathrm{~cm}^{3} / \mathrm{g}, \quad 0.041 \pm$ $0.012 \mathrm{~cm}^{3} / \mathrm{g}, 0.325 \pm 0.023 \mathrm{~cm}^{3} / \mathrm{g}$, respectively. All solutions were prepared from chemicals provided by Merck Chemicals Company, Germany. A pH meter (model $420 \mathrm{~A}$ ) was used for $\mathrm{pH}$ measurements. Strong acid $(0.1 \mathrm{~N} \mathrm{HCl})$ and base $\left(0.1 \mathrm{~N} \mathrm{NaHCO}, \mathrm{Na}_{2} \mathrm{CO}_{3}\right.$, and $\mathrm{NaOH}$ ) were used for the analysis of surface functional group. Unless otherwise mentioned, strong acid $\left(0.1 \mathrm{M} \mathrm{HClO}_{4}\right)$ and strong base $(0.2 \mathrm{M} \mathrm{NaOH})$ were used for all $\mathrm{pH}$ adjustments.

\subsection{Chemical treatment of activated carbon}

$500 \mathrm{~g}$ of activated carbon was weighed and placed into each of the five 2-1 polyethylene bottles. 11 of $\mathrm{NaOH}$ solution at various concentrations was added to each of the five bottles containing the activated carbon. The bottles were then placed on a rotating vibrator and mixed constantly for $24 \mathrm{~h}$. The activated carbon was then separated from the solution and placed in an oven at $105^{\circ} \mathrm{C}$ and dried for $48 \mathrm{~h}$. The $\mathrm{NaOH}$-treated activated carbon samples were divided into two parts. One part received further ozone treatment at an inflow concentration of $40 \mathrm{mg} / \mathrm{l}$ and flow rate of $2.5 \mathrm{1} / \mathrm{min}$ (or mass rate of $100 \mathrm{mg} / \mathrm{min}$ ) for $30 \mathrm{~min}$. The reaction temperature was controlled at level below the combustion point of the activated carbon using a water tank.

Both activated carbon samples were washed with distilled water until the sodium ion concentration of the rinsed water reached that of the distilled water. The activated carbon was dried in an oven at $105^{\circ} \mathrm{C}$ for $48 \mathrm{~h}$ then transferred to a desiccator until use.

\subsection{IR spectrum analysis}

The activated carbon samples were ground in an agate motar to fine powder. The activated carbon powder was mixed with $\mathrm{KBr}$ by a weight ratio of 700:1. A given amount of the mixture $(200 \mathrm{mg})$ was used for the preparation of $\mathrm{KBr}$ pellets. The $\mathrm{KBr}$ pellets were stored in a desiccator until IR analysis. The IR instrument was a Bomem, model DA 3.002 FTIR. The IR spectrum was obtained over a frequency between 500 and $4000 \mathrm{~cm}^{-1}$.

\subsection{Boehm titration}

Procedures for the analysis of oxygen functional group follow those established by Boehm (Puri and Bansal, 1964; Boehm, 1966; Barton et al., 1973; Fabish and Schleifer, 1984; Magane and Dupong-Parlovskky, 1988; Arico et al., 1989). The activated carbon samples were first dried in a vacuum oven $\left(10^{-2}-10^{-3} \mathrm{~mm} \mathrm{Hg}\right.$, $\left.105{ }^{\circ} \mathrm{C}\right)$ for $24 \mathrm{~h} .25 \mathrm{ml}$ of an alkali solution $(0.1 \mathrm{~N}$ $\mathrm{NaHCO}_{3}, \mathrm{Na}_{2} \mathrm{CO}_{3}$, or $\mathrm{NaOH}$ ) were added to test tubes containing a given amount of the activated carbon sample $(5 \mathrm{~g})$. The samples were constantly mixed over a vibrator $(100 \mathrm{rpm})$ at $25^{\circ} \mathrm{C}$ for $24 \mathrm{~h}$. A given amount of the supernatant $(5 \mathrm{ml})$ was then drawn from the test tubes and back titrated with $\mathrm{HC} 1(0.1 \mathrm{~N})$ solution. The concentrations of various functional groups were determined by the residual bases after back titration as described by Boehm (1966).

\subsection{Electrophoretic mobility measurements}

Zeta potential measurements of activated carbons were made with Zeta Meter System 3.0. The activated carbon $(5 \mathrm{~g})$ was placed in a porcelain mortar and ground to fine powder. A given amount of the activated carbon powder $(100 \mathrm{mg})$ was added to 11 distilled water. After mixing for several minutes, the coarse particles 
were allowed to settle, and the colloidal size particles were collected for electrophoretic mobility measurements. After electrolyte addition $\left(10^{-2} \mathrm{M} \mathrm{NaCl}\right)$ and $\mathrm{pH}$ adjustment, the activated carbon suspension was placed in the electrophoresis cell for zeta potential measurements.

\subsection{Surface acidity determination}

The surface acidity of the activated carbon was determined according to concept and procedures proposed by Huang and associates (Corapcioglu and Huang, 1987). Upon hydration, the surface acidity develops on the activated carbon

$\underline{\mathrm{COH}_{2}}=\underline{\mathrm{COH}}+\mathrm{H}^{+} ; \quad K_{\mathrm{a} 1}^{\mathrm{int}}$

$\underline{\mathrm{COH}}=\underline{\mathrm{CO}}^{-}+\mathrm{H}^{+} ; \quad K_{\mathrm{a} 2}^{\mathrm{int}}$

where $\underline{\mathrm{COH}}_{2}^{+}, \mathrm{COH}$, and $\mathrm{CO}^{-}$represent protonated, neutral and ionized surface hydroxyl groups, respectively. The intrinsic acidity constant, $K_{\mathrm{a} 1}^{\text {int }}$ and $K_{\mathrm{a} 2}^{\mathrm{int}}$ are defined as follows:

$K_{\mathrm{a} 1}^{\mathrm{int}}=\{\underline{\mathrm{COH}}\}\left\{\mathrm{H}^{+}\right\} /\left\{\underline{\mathrm{COH}}_{2}^{+}\right\}$

$K_{\mathrm{a} 2}^{\mathrm{int}}=\left\{\underline{\mathrm{CO}}^{-}\right\}\left\{\mathrm{H}^{+}\right\} /\{\underline{\mathrm{COH}}\}$

where $i$ stands for the surface concentration of the $i$ th species. The total number of surface Bronsted acidity site, $N_{\mathrm{B}}$, is therefore the sum of all the three surface hydroxo groups, i.e.,

$N_{\mathrm{B}}=\left\{\underline{\mathrm{COH}}_{2}^{+}\right\}+\{\underline{\mathrm{COH}}\}+\left\{\underline{\mathrm{CO}}^{-}\right\}$

The surface proton concentration is not directly measurable; rather it is calculated from the $\mathrm{pH}$ measurements in the bulk phase, i.e., $\left\{\mathrm{H}^{+}\right\}_{\mathrm{b}}$, and by the Boltzmann equation

$$
\left\{\mathrm{H}^{+}\right\}=\left\{\mathrm{H}^{+}\right\}_{\mathrm{b}} \exp \left(-F \psi_{\mathrm{o}} / R T\right)
$$

where $\psi_{\mathrm{o}}, F, R, T$ denote the surface potential, Faraday constant, gas law constant and absolute temperature, respectively. The surface potential is not a directly measurable quantity. In a dilute inert electrolyte solution, the surface potential, $\psi_{\mathrm{o}}$, is close to the potential at the outer Helmholtz plane, or the diffuse layer potential, $\psi_{\mathrm{d}} \cdot \mathrm{H}^{+}$and $\mathrm{OH}^{-}$are considered the sole potential determining ions, as indicated by the change of electrophoretic mobility at different $\mathrm{pH}$ values. In the absence of specific adsorption such as in dilute inert electrolyte solution, the surface charge obtained from alkalimetric titration can be set equal to the diffuse layer charge, $\sigma_{\mathrm{d}}$. The surface potential can therefore be calculated by the Gouy-Chapman electrical double layer theory (Corapcioglu and Huang, 1987; Hunter, 1987)
$\Psi_{\mathrm{o}} \cong \Psi_{\mathrm{d}}=(2 R T / z F) \sinh ^{-1}[\sqrt{\pi / 2 R T \varepsilon I}] \sigma_{\mathrm{d}}$,

where $z, \epsilon$, and $I$ are absolute valence of (1:1) electrolyte, dielectric constants of water and ionic strength, respectively. In aqueous solution at $20{ }^{\circ} \mathrm{C}$, Eq. (6) can be further simplified (Corapcioglu and Huang, 1987)

$\Psi_{\mathrm{o}}=0.05 \sinh ^{-1}\left[\frac{\sigma_{\mathrm{d}}}{11.7 \sqrt{I}}\right]$

The unit for $\psi_{\mathrm{o}}, \sigma_{\mathrm{d}}$ and $I$ in Eq. (7) are volt, $\mu \mathrm{C} / \mathrm{cm}^{2}$, and $\mathrm{M}$, respectively. As shown above, at $\mathrm{pH}<\mathrm{pH}_{\mathrm{zpc}}$ the surface is predominately positively charged, therefore

$N_{\mathrm{B}} \cong\left\{\underline{\mathrm{COH}}_{2}^{+}\right\}+\{\underline{\mathrm{COH}}\}$

Similarly, at $\mathrm{pH}>\mathrm{pH}_{\mathrm{Zpc}}$, the surface is negatively charged

$N_{\mathrm{B}} \cong\{\underline{\mathrm{COH}}\}+\left\{\underline{\mathrm{CO}}^{-}\right\}$

The quantity for the term $\{\underline{\mathrm{COH}}\}$ and $\left\{\mathrm{CO}^{-}\right\}$are determined from alkalimetric titration, i.e.,

$\left\{\underline{\mathrm{COH}_{2}^{+}}\right\}=\sigma_{+} / S$

and

$\left\{\mathrm{CO}^{-}\right\}=\sigma_{-} / S$

where $\sigma_{+}, \sigma_{-}$are positive surface charge and negative surface charge, respectively. $S$ is a charge conversion factor from $\mathrm{C} / \mathrm{cm}^{2}$ to surface concentration (mol/g or $\left.\mathrm{mol} / \mathrm{cm}^{3}\right)$. By substituting the above relationships into Eqs. (3a) and (3b) and with further mathematical arrangement, one has

$1 /\left\{\mathrm{H}^{+}\right\}=N_{\mathrm{B}} / K_{\mathrm{a} 1}^{\mathrm{int}}\left(1 / \sigma_{+}\right)-\left(1 / K_{\mathrm{a} 1}^{\mathrm{int}}\right) \quad$ at $\mathrm{pH}<\mathrm{pH}_{\mathrm{zpc}}$

and

$$
\left\{\mathrm{H}^{+}\right\}=N_{\mathrm{B}} / K_{\mathrm{a} 2}^{\mathrm{int}}\left(1 / \sigma_{-}\right)-\left(1 / K_{\mathrm{a} 2}^{\mathrm{int}}\right) \quad \text { at } \mathrm{pH}<\mathrm{pH}_{\mathrm{zpc}} .
$$

A plot of $1 /\left\{\mathrm{H}^{+}\right\}$versus $1 / \sigma_{+}$for the positive surface and of $\left\{\mathrm{H}^{+}\right\}$versus $1 / \sigma_{-}$for the negative surface will yield intercepts and slopes from which the intrinsic acidity constants, $K_{\mathrm{a} 1}^{\mathrm{int}}$ and $K_{\mathrm{a} 2}^{\mathrm{int}}$, and total surface acidity capacity, $N_{\mathrm{B}}$, can be calculated. This method has been used previously by Huang and Stumm for their studies of hydrous oxide systems (Huang and Stumm, 1973; Huang, 1981; Corapcioglu and Huang, 1987). 


\section{Results and discussion}

\subsection{Surface functional groups - IR analysis}

IR results in Table 1 show clearly that the $\mathrm{C}-\mathrm{C}$ band (normal paraffin alkanes), out of plane $\mathrm{C}-\mathrm{C}$ band, and the aromatic $\mathrm{CH}$ band position are at 497-521, 661-680 and $777-802 \mathrm{~cm}^{-1}$, respectively. There are two absorption bands at 917-934 and 1382-1392 $\mathrm{cm}^{-1}$, which can be attributed to the $\mathrm{COOH}$ band. The absorption positions of the C-bands are 1187-1205 and $1272 \mathrm{~cm}^{-1}$, individually. The absorption bands of $\mathrm{C}=\mathrm{C}$ double bonds are $1560-1572$ and $1633-1639 \mathrm{~cm}^{-1}$. There is a weak band at $1723 \mathrm{~cm}^{-1}$ in the sodium salt treated activated carbon, which may be a normal carbonyl group. Magane and Dupong-Parlovskky (1988) have proposed that $\mathrm{NaOH}$ reaction with unsaturated $n$-lactones will form both carboxylate anions and a normal carbonyl group in the form of an aldehyde. The spectra of activated carbon observed show a chemical shift which is due to the reaction of $\mathrm{NaOH}$ and $\mathrm{O}_{3}$ with activated carbon.

\subsection{Surface functional groups - Boehm's titration carb-} oxylic, lactone, and phenolic groups

The Boehm titration method allows the determination of the surface functional groups such as phenolic group $(-\mathrm{OH})$, lactone group $(\mathrm{C}=\mathrm{O})$ and carboxylic group $(-\mathrm{COOH})$. Fig. 1 shows the results of surface functional groups of various activated carbon samples by the Boehm method.
For virgin activated carbon (AC), the total oxygen containing function group is $0.196 \mathrm{meq} / \mathrm{g}$ with a breakdown of $0.117 \mathrm{meq} / \mathrm{g}(60 \%), 0.046 \mathrm{meq} / \mathrm{g}(23 \%)$, and $0.034 \mathrm{meq} / \mathrm{g}(17 \%)$, individually, for phenolic, lactone and carboxylic groups. When treated with $\mathrm{O}_{3}$, the total oxygen containing functional group increases to 0.240 $\mathrm{meq} / \mathrm{g}$, which is an increase of $22 \%$ compared to the untreated AC. Increase in oxygen containing functional groups, takes mostly in the phenolic and lactone categories. The phenolic group increases from 0.117 to 0.144 $\mathrm{meq} / \mathrm{g}$ and the lactone group increases from 0.034 to $0.052 \mathrm{meq} / \mathrm{g}$. The concentration of the carboxylic group slightly increases from 0.034 to $0.044 \mathrm{meq} / \mathrm{g}$ upon $\mathrm{O}_{3}$ treatment. It is interesting to note that the composition among these three oxygen containing functional groups remains relatively unchanged compared to $\mathrm{AC}$, that is, $60 \%$ versus $60 \%, 22 \%$ versus $23 \%$ and $18 \%$ versus $17 \%$ for the phonemic, lactone and carboxylic groups respectively, between $\mathrm{AC}\left(\mathrm{O}_{3}\right)$ and $\mathrm{AC}$.

Treatment of AC with $\mathrm{NaOH}(1-5 \mathrm{~N})$ increases the total concentration of the oxygen containing functional groups from $0.196 \mathrm{meq} / \mathrm{g}$ to between 0.275 and 0.309 meq/g dependent on the $\mathrm{NaOH}$ concentration. This is an increase of almost $40-88 \%$. As far as the individual oxygen containing functional groups are concerned, the phenolic group increases from 0.117 to between 0.143 and $0.204 \mathrm{meq} / \mathrm{g}$, the lactone group increases from 0.046 to between 0.073 and $0.096 \mathrm{meq} / \mathrm{g}$ and the carboxylic group increases from 0.034 to between 0.053 and 0.094 $\mathrm{meq} / \mathrm{g}$. Like the ozone-treated activated carbon, the major increase takes place in the phenolic group.

Tryk et al. (1984) proposed the following reaction between $\mathrm{NaOH}$ and activated carbon:

Table 1

IR spectra of activated carbon treated with ozone and $\mathrm{NaOH}(\mathrm{N}=2)$

\begin{tabular}{|c|c|c|c|c|c|c|c|c|c|c|c|c|}
\hline \multirow[t]{2}{*}{ Vibration group } & \multicolumn{12}{|c|}{ Adsorption peaks $\left(\mathrm{cm}^{-1}\right)$} \\
\hline & $\mathrm{A}$ & B & $\mathrm{C}$ & $\mathrm{D}$ & $\mathrm{E}$ & $\mathrm{F}$ & G & $\mathrm{H}$ & I & $\mathrm{J}$ & $\mathrm{K}$ & $\mathrm{L}$ \\
\hline $\begin{array}{l}\mathrm{C}-\mathrm{C} \text { band (Normal } \\
\text { paraffins alkanes) }\end{array}$ & 509 & 520 & 520 & 508 & 515 & 515 & 521 & 508 & 505 & 497 & 507 & 515 \\
\hline $\begin{array}{l}\text { Out of plane ring } \\
\mathrm{C}-\mathrm{C} \text { band }\end{array}$ & 680 & 673 & 661 & 667 & 661 & 680 & 667 & 675 & 667 & 663 & - & - \\
\hline $\begin{array}{l}\text { Out of plane } \\
\text { aromatic } \mathrm{C}-\mathrm{H} \text { band }\end{array}$ & 790 & 790 & 777 & 802 & 784 & 796 & 777 & - & 802 & - & - & - \\
\hline $\mathrm{COOH}$ & $\begin{array}{r}924 \\
1389\end{array}$ & $\begin{array}{r}918 \\
1389\end{array}$ & $\begin{array}{l}- \\
1389\end{array}$ & $\begin{array}{r}924 \\
1395\end{array}$ & $\begin{array}{r}931 \\
1382\end{array}$ & $\begin{array}{r}924 \\
1395\end{array}$ & - & $\begin{array}{r}936 \\
1394\end{array}$ & $\begin{array}{l}- \\
1389\end{array}$ & $\begin{array}{r}917 \\
1388\end{array}$ & $\begin{array}{l}- \\
1389\end{array}$ & $\begin{array}{l}- \\
1896\end{array}$ \\
\hline $\mathrm{C}-\mathrm{O}-\mathrm{C}$ & 1199 & 1205 & $\begin{array}{l}1187 \\
1272\end{array}$ & 1205 & 1205 & 1193 & 1193 & 1196 & 1199 & 1208 & 1193 & 1193 \\
\hline $\mathrm{C}=\mathrm{C}$ & $\begin{array}{l}1572 \\
1633\end{array}$ & $\begin{array}{l}1567 \\
-\end{array}$ & $\begin{array}{l}1572 \\
-\end{array}$ & $\begin{array}{l}1572 \\
-\end{array}$ & $\begin{array}{l}1572 \\
-\end{array}$ & $\begin{array}{l}1572 \\
-\end{array}$ & $\begin{array}{l}1560 \\
-\end{array}$ & $\begin{array}{l}1587 \\
-\end{array}$ & $\begin{array}{l}1572 \\
1639\end{array}$ & $\begin{array}{l}1562 \\
-\end{array}$ & $\begin{array}{l}1566 \\
-\end{array}$ & $\begin{array}{l}1572 \\
-\end{array}$ \\
\hline $\mathrm{C}=\mathrm{O}^{\mathrm{a}}$ & - & - & - & - & - & - & - & 1723 & - & 1723 & - & - \\
\hline $\mathrm{CH}_{3}$ & - & - & - & - & - & 2630 & 2373 & 2951 & 2366 & - & 2360 & - \\
\hline$-\mathrm{OH}$ & 3461 & 3472 & 3436 & 3436 & 3461 & 3448 & 3485 & 3435 & 3436 & 3453 & 3454 & 3442 \\
\hline
\end{tabular}

Note. A: VAC, B: AC(O $\left.{ }_{3}\right), \mathrm{C}: \mathrm{AC}(1 \mathrm{~N} \mathrm{NaOH}), \mathrm{D}: \mathrm{AC}(2 \mathrm{~N} \mathrm{NaOH}), \mathrm{E}: \mathrm{AC}(3 \mathrm{~N} \mathrm{NaOH}), \mathrm{F}: \mathrm{AC}(4 \mathrm{~N} \mathrm{NaOH}), \mathrm{G}: \mathrm{AC}(5 \mathrm{~N} \mathrm{NaOH}), \mathrm{H}$ : $\mathrm{AC}\left(1 \mathrm{~N} \mathrm{NaOH}+\mathrm{O}_{3}\right), \mathrm{I}: \mathrm{AC}\left(2 \mathrm{~N} \mathrm{NaOH}+\mathrm{O}_{3}\right), \mathrm{J}: \mathrm{AC}\left(3 \mathrm{~N} \mathrm{NaOH}+\mathrm{O}_{3}\right), \mathrm{K}: \mathrm{AC}\left(4 \mathrm{~N} \mathrm{NaOH}+\mathrm{O}_{3}\right), \mathrm{L}: \mathrm{AC}\left(5 \mathrm{~N} \mathrm{NaOH}+\mathrm{O}_{3}\right)$.

${ }^{\mathrm{a}}$ Unsaturated $\beta$-lactones. 


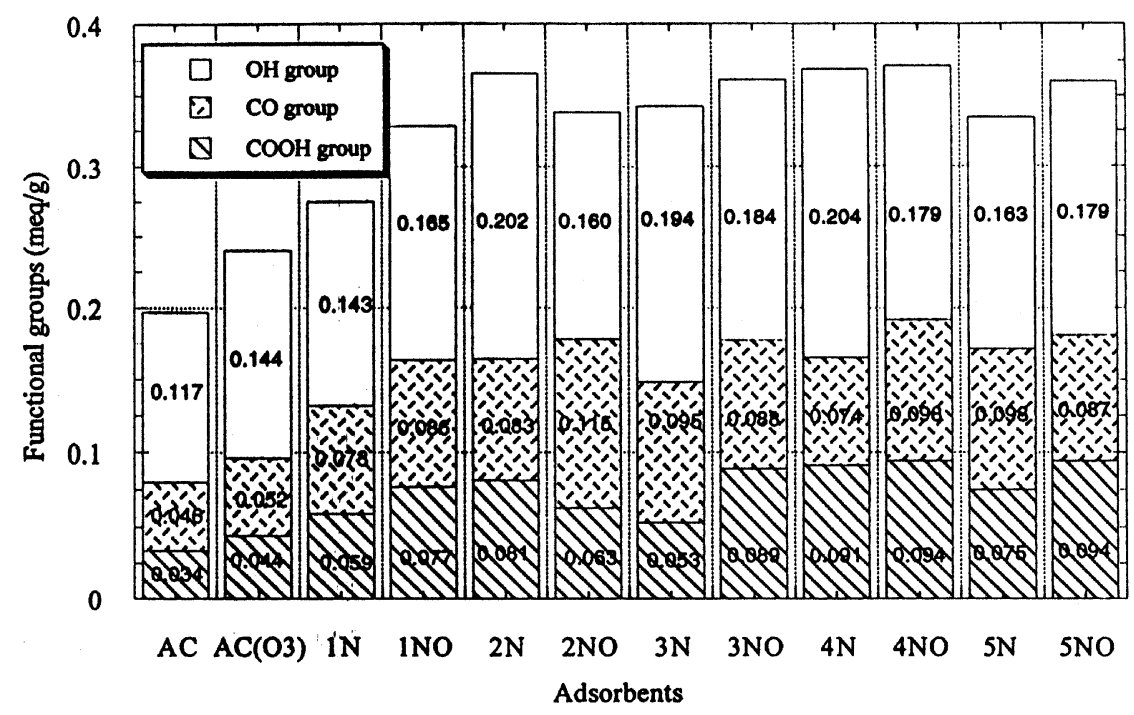

Fig. 1. Intensity of surface oxygen containing functional group as affected by $\mathrm{O}_{3}$ and $\mathrm{NaOH}$. Adsorbents: $\mathrm{A}=\mathrm{AC}, \mathrm{B}=\mathrm{AC}\left(\mathrm{O}_{3}\right), 1 \mathrm{~N}$ : $A C(1 \mathrm{~N} \mathrm{NaOH}), 2 \mathrm{~N}: \mathrm{AC}(2 \mathrm{~N} \mathrm{NaOH}), 3 \mathrm{~N}: \mathrm{AC}(3 \mathrm{~N} \mathrm{NaOH}), 4 \mathrm{~N}: \mathrm{AC}(4 \mathrm{~N} \mathrm{NaOH}), 5 \mathrm{~N}: A C(5 \mathrm{~N} \mathrm{NaOH}), 1 \mathrm{NO}: \mathrm{AC}\left(1 \mathrm{~N} \mathrm{NaOH}+\mathrm{O}_{3}\right)$, 2NO: $\mathrm{AC}\left(2 \mathrm{~N} \mathrm{NaOH}+\mathrm{O}_{3}\right), 3 \mathrm{NO}: \mathrm{AC}\left(3 \mathrm{~N} \mathrm{NaOH}+\mathrm{O}_{3}\right), 4 \mathrm{NO}: \mathrm{AC}\left(4 \mathrm{~N} \mathrm{NaOH}+\mathrm{O}_{3}\right), 5 \mathrm{NO}: \mathrm{AC}\left(5 \mathrm{~N} \mathrm{NaOH}+\mathrm{O}_{3}\right)$.

$\mathrm{C}+6 \mathrm{OH}^{-}=\mathrm{CO}_{3}^{2-}+3 \mathrm{H}_{2} \mathrm{O}+4 \mathrm{e}^{-}$

$\Delta \mathrm{G}^{\circ}=-70.72 \mathrm{kcal} /$ mole .

It is further known that

$4 \mathrm{H}^{+}+\mathrm{O}_{2}+4 \mathrm{e}^{-}=2 \mathrm{H}_{2} \mathrm{O}$

$\Delta \mathrm{G}^{\circ}=-113.38 \mathrm{kcal} /$ mole.

Combining Eqs. (12) and (13), one has

$\mathrm{C}+2 \mathrm{OH}^{-}+\mathrm{O}_{2}=\mathrm{CO}_{3}^{2-}+\mathrm{H}_{2} \mathrm{O}$

$\Delta \mathrm{G}^{\circ}=-184.10 \mathrm{kcal} / \mathrm{mole}$.

The following shows the conceptual scheme of $\mathrm{NaOH}$ reaction with activated carbon:

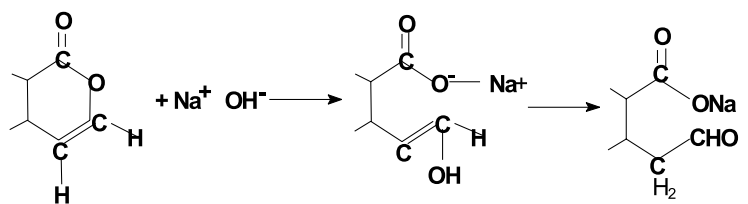

Treatment of $\mathrm{AC}$ with combined $\mathrm{NaOH}$ and $\mathrm{O}_{3}$ increases the oxygen containing functional group even further. Results indicate that the total oxygen containing functional group increases from 0.197 (AC) to 0.275$0.369 \mathrm{meq} / \mathrm{g} \quad(\mathrm{NaOH}-\mathrm{AC})$ to $0.328-0.371 \mathrm{meq} / \mathrm{g}$ $\left(\mathrm{AC}\left(\mathrm{O}_{3}\right)-\mathrm{NaOH}\right)$. This is an increase by $67-85 \%$ compared to the untreated $\mathrm{AC}$. The concentration of phen- olic group increases from 0.117 to $0.143-0.202 \mathrm{meq} / \mathrm{g}$ $(\mathrm{NaOH}-\mathrm{AC})$ to $0.165-0.184 \mathrm{meq} / \mathrm{g}\left(\mathrm{AC}\left(\mathrm{O}_{3}\right)-\mathrm{NaOH}\right)$. The concentration of lactone group increases from 0.046 (AC) to $0.052-0.098 \mathrm{meq} / \mathrm{g}(\mathrm{NaOH}-\mathrm{AC})$ to $0.086-0.115 \mathrm{meq} / \mathrm{g}\left(\mathrm{AC}\left(\mathrm{O}_{3}\right)-\mathrm{NaOH}\right)$. The concentration of the carboxylic group increases from 0.034 (VAC) to $0.053-0.091 \mathrm{meq} / \mathrm{g}(\mathrm{NaOH}-\mathrm{AC})$ to $0.063-0.094 \mathrm{meq} / \mathrm{g}$ $\left(\mathrm{AC}\left(\mathrm{O}_{3}\right)-\mathrm{NaOH}\right)$.

\subsection{Reaction pathways}

Results show that major functional groups of the treated activated carbon include phenolic, lactone, carboxylic, carbon-hydrogen bond and carbon-carbon double bonds. Results of the Boehm titration and FTIR analysis clearly indicate that hydroxyl carbonyl, carboxylic, $\mathrm{C}-\mathrm{H}$ and $\mathrm{C}=\mathrm{C}$ bonds are the major surface functional groups. Based on the literature (Schubert and Pease, 1956b,c; Schubert and Pease, 1956c), a conceptual reaction pathway can be proposed (Fig. 2).

The surface of activated carbon is thought to be assemblies of hexagon structure (a) and the reaction site is at the carbon-hydrogen bond. The reaction of carbonhydrogen bond and ozone follows two pathways, one is the formation of hydroxide compounds (b) and the other is the generation of hydrotrioxide intermindates (c). The hydroxide site may be further transformed to carbon-carbon double bond (d). The hydrotrioxide intermindates will undergo three reaction pathways. First, hydrotrioxide losses a hydrogen peroxide $\left(\mathrm{H}_{2} \mathrm{O}_{2}\right)$ to form the carbon-oxygen double bond (e). Second, the 


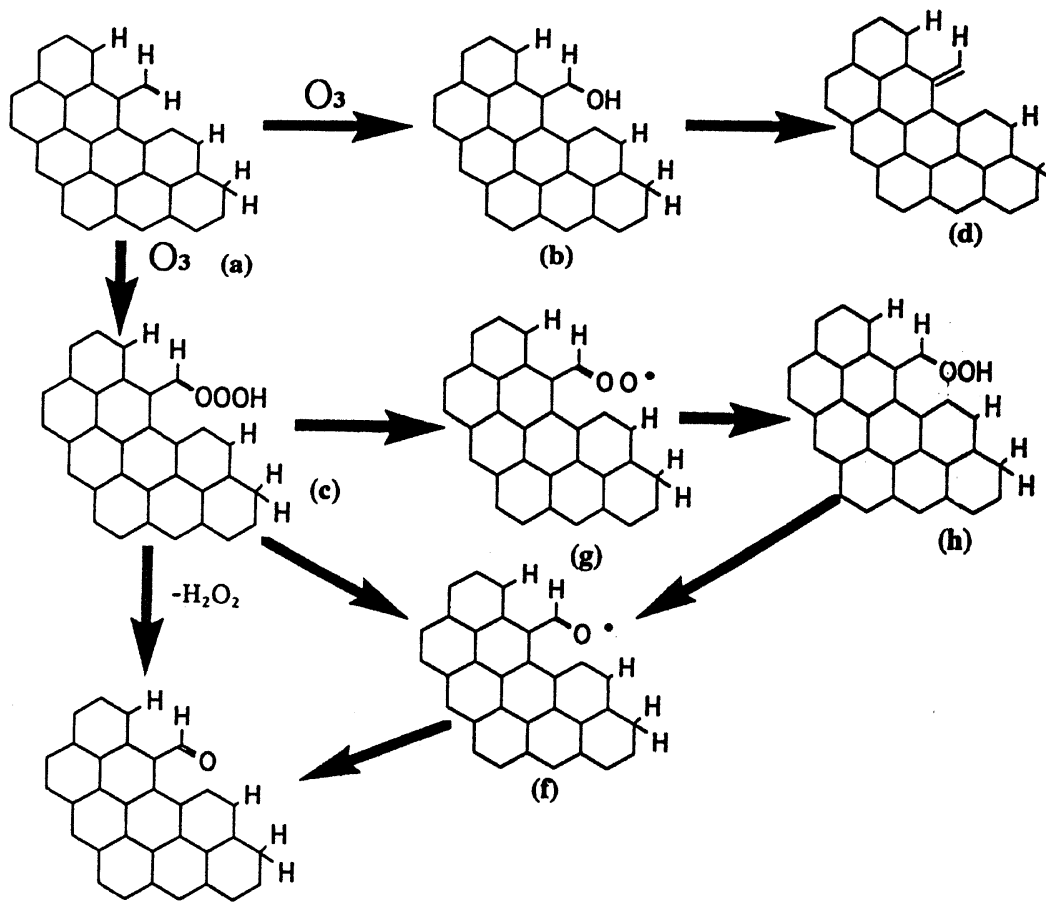

(e)

Fig. 2. Proposed reaction pathways for $\mathrm{O}_{3}$ reaction with activated carbon.

hydrotrioxide loses an $\mathrm{O}_{2} \mathrm{H}$ to produce radical $\left(\mathrm{O}^{\bullet}\right)$ (f). Third, the deprotonation of hydrotrioxide yields the peroxide radical $\left(\mathrm{OO}^{\bullet}\right)(\mathrm{g})$. The peroxide and oxygen radical compounds may be further transformed to carboxyl compounds and subsequently carbonyl compounds (h).

\subsection{Surface acidity}

The presence of surface functional groups such as hydroxyl, carboxyl, and carbonyl on activated carbon can bring about surface charge upon hydration. This is evident of the fact that a positive charge evolves when introducing an H-type activated carbon into water. Likewise, a negative charge is observed on the L-type activated carbon when it is placed in water (Huang, 1981).

Fig. 3 shows the zeta potential of various activated carbon samples as a function of $\mathrm{pH}$. Generally, a flesh $\mathrm{H}$-carbon has a $\mathrm{pH}_{\mathrm{zpc}}$ of $\sim 7$. The $\mathrm{pH}_{\mathrm{zpc}}$ value shifts to 5.3 upon exposure to atmosphere over an extended period of time which is indicative of an L-type conversion. Exposing an $\mathrm{H}$-carbon to the atmosphere tends to gradually oxidize the carbon and converting it to an L-carbon. Upon treatment with ozone and sodium hydroxide, the $\mathrm{pH}_{\mathrm{zpc}}$ shifts to $\mathrm{pH}<2$, which clearly indicates an oxidizing surface on the activated carbon.

Table 2 summarizes the total surface acidity density obtained by alkalimetric titration and the Boehm method. Results indicate that alkalimetric titration yields a total surface acidity larger than the Boehm titration. This can be attributed to the extra surface charge contributed by other functional groups such as sulfur and nitrogen which cannot be detected by the Boehm method.

\section{Conclusions}

Ozone and $\mathrm{NaOH}$ treatment of activated carbon results in an increase of surface oxygen functional groups, especially in the phenolic and carboxylic categories. Because the increase in the formation energy of lactone is greater than that of other functional groups, the increase of lactone group intensity on activated carbon is not significant by either ozone or $\mathrm{NaOH}$ treatment. Based on the results obtained from this study and reported literature information, a preliminary pathway for $\mathrm{O}_{3}$ reaction with activated carbon can be proposed. The reaction of carbon-hydrogen bond and ozone follows 

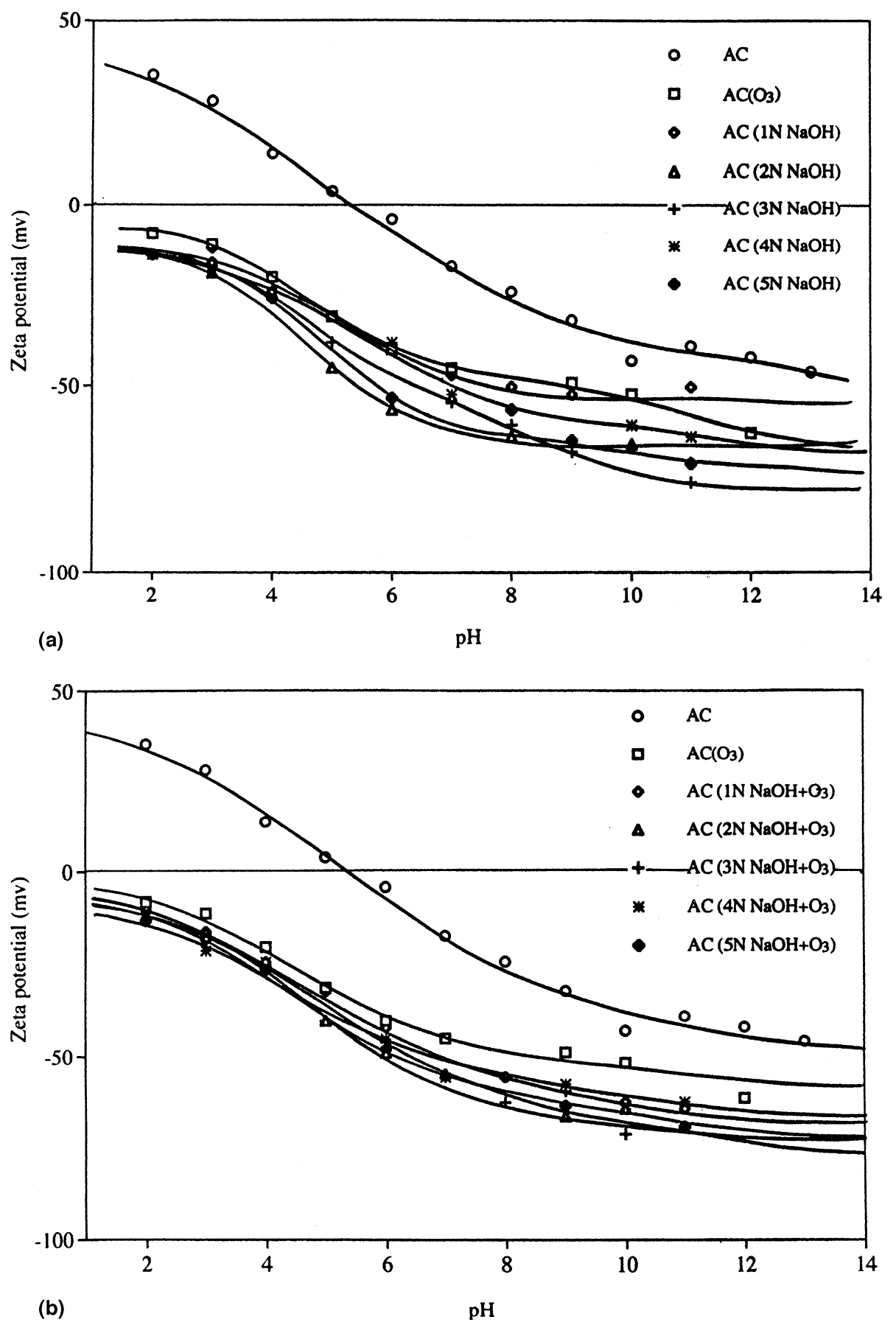

Fig. 3. (a) Effect of $\mathrm{NaOH}$ treatment on the zeta potential of activated carbon. (b) Effect of $\mathrm{O}_{3}$ treatment on the zeta potential of activated carbon.

two pathways, one is the formation of hydroxide compounds and the other is the generation of hydrotrioxide intermindates. The hydroxide site may be further transformed to carbon-carbon double bond. The hydrotrioxide intermindates will undergo three reaction pathways: First, the hydrotrioxide losses a hydrogen 
Table 2

Effect of $\mathrm{O}_{3}$ and $\mathrm{NaOH}$ treatment on the surface acidity of activated carbon ${ }^{\mathrm{a}}$

\begin{tabular}{|c|c|c|c|c|c|}
\hline \multirow[t]{2}{*}{ Adsorbents ${ }^{\mathrm{b}}$} & \multicolumn{2}{|c|}{ Ionic strength $5 \times 10^{-2} \mathrm{M}^{\mathrm{c}}$} & \multirow[t]{2}{*}{$\mathrm{pH}_{\mathrm{zpc}}^{\mathrm{d}}$} & \multirow[t]{2}{*}{ Zeta potential- $N_{\mathrm{B}}\left(\mu \mathrm{C} / \mathrm{cm}^{2}\right)$} & \multirow[t]{2}{*}{ Boehm's method- $N_{\mathrm{B}}\left(\mu \mathrm{C} / \mathrm{cm}^{2}\right)$} \\
\hline & $\mathrm{p} K_{\mathrm{a} 1}^{\mathrm{int}}$ & $\mathrm{p} K_{\mathrm{a} 2}^{\mathrm{int}}$ & & & \\
\hline A & 4.09 & 6.25 & 5.30 & 3.01 & 2.42 \\
\hline B & $(-0.67)$ & 4.67 & 2.00 & 10.54 & 2.72 \\
\hline $\mathrm{C}$ & $(-0.79)$ & 4.79 & 2.00 & 6.85 & 3.21 \\
\hline $\mathrm{D}$ & $(-0.16)$ & 4.16 & 2.00 & 6.60 & 4.23 \\
\hline $\mathrm{E}$ & $(-0.84)$ & 4.84 & 2.00 & 9.54 & 3.92 \\
\hline $\mathrm{F}$ & $(-0.83)$ & 4.83 & 2.00 & 8.84 & 4.40 \\
\hline G & $(-0.40)$ & 4.40 & 2.00 & 7.29 & 3.88 \\
\hline $\mathrm{H}$ & $(-0.79)$ & 4.79 & 2.00 & 13.00 & 3.88 \\
\hline I & $(-0.79)$ & 4.79 & 2.00 & 8.78 & 3.97 \\
\hline $\mathrm{J}$ & $(-0.74)$ & 4.74 & 2.00 & 8.97 & 4.26 \\
\hline $\mathrm{K}$ & $(-1.19)$ & 5.19 & 2.00 & 7.92 & 4.28 \\
\hline $\mathrm{L}$ & $(-0.27)$ & 4.27 & 2.00 & 9.28 & 4.24 \\
\hline
\end{tabular}

${ }^{\mathrm{a}}$ The concentration of activated carbon is $100 \mathrm{mg}-\mathrm{PAC} / \mathrm{l}-\mathrm{NaClO}_{4}$ (aq) and experiment is performed in closed system at $25{ }^{\circ} \mathrm{C}$.

${ }^{\mathrm{b}} \mathrm{A}: \mathrm{VAC}, \mathrm{B}: \mathrm{AC}\left(\mathrm{O}_{3}\right), \mathrm{C}: \mathrm{AC}(1 \mathrm{~N} \mathrm{NaOH}), \mathrm{D}: \mathrm{AC}(2 \mathrm{~N} \mathrm{NaOH}), \mathrm{E}: \mathrm{AC}(3 \mathrm{~N} \mathrm{NaOH}), \mathrm{F}: \mathrm{AC}(4 \mathrm{~N} \mathrm{NaOH}), \mathrm{G}: \mathrm{AC}(5 \mathrm{~N} \mathrm{NaOH}), \mathrm{H}$ : $\mathrm{AC}\left(1 \mathrm{~N} \mathrm{NaOH}+\mathrm{O}_{3}\right), \mathrm{I}: \mathrm{AC}\left(2 \mathrm{~N} \mathrm{NaOH}+\mathrm{O}_{3}\right), \mathrm{J}: \mathrm{AC}\left(3 \mathrm{~N} \mathrm{NaOH}+\mathrm{O}_{3}\right), \mathrm{K}: \mathrm{AC}\left(4 \mathrm{~N} \mathrm{NaOH}+\mathrm{O}_{3}\right), \mathrm{L}: \mathrm{AC}\left(5 \mathrm{~N} \mathrm{NaOH}+\mathrm{O}_{3}\right)$.

${ }^{\mathrm{c}} \mathrm{NaClO}_{4}$ as inert electrolyte.

${ }^{\mathrm{d}} \mathrm{pH}_{\mathrm{zpc}}=\left(\mathrm{p} K_{\mathrm{a} 1}^{\mathrm{int}}+\mathrm{p} K_{\mathrm{a} 2}^{\mathrm{int}}\right) / 2$.

peroxide $\left(\mathrm{H}_{2} \mathrm{O}_{2}\right)$ to form carbon-oxygen double bond. Second, the hydrotrioxide losses an $\mathrm{O}_{2} \mathrm{H}$ to form radical $\left(\mathrm{O}^{\bullet}\right)$. Third, the hydrotrioxide deprotonates to form peroxide radical $\left(\mathrm{OO}^{\bullet}\right)$. The peroxide and oxygen radical compounds may be further transformed to carboxylic compounds and subsequently lactone compounds. Alkalimetric titration gives a surface acidity larger than the Boehm titration due in part to the extent of neutralization reaction.

\section{References}

Arico, A.S., Antonucci, V., Minutoli, M., Giordano, N., 1989. The influence of functional groups on the surface acid-base characteristics of carbon blacks. Carbon 27, 337-347.

Bailey, P.S., 1982. Ozonation in Organic Chemistry, vol. II. Nolefinic Compounds. Academic Press, New York.

Bansal, R.C., Donnet, J.B., Stoeckli, F., 1990. Active Carbon. Marcel Dekker, New York.

Barton, S.S., Gillespie, D., Harrison, B.H., 1973. Surface studies of carbon: acidic oxides on Speron 6. Carbon 11, 649-654

Boehm, H.P., 1966. Chemical identification of surface groups. In: Eley, D.D., Pines, H., Weisz, P.B. (Eds.), Advances in Catalysis, vol. 16. Academic Press, New York, p. 179.

Chiang, H.L., Huang, C.P., Chiang, P.C., Chang, E.E., 1999. Effect of metal additives on the physico-chemical characteristics of activated carbon exemplified by benzene and acetic acid adsorption. Carbon 37, 1919-1928.

Cookson, J.T., 1978. Adsorption mechanism: the chemistry of organic adsorption on activated carbon. In: Cheremisinoff, P.N., Ellerbursch, F. (Eds.), Carbon Adsorption Handbook. Ann Arbor Science, New York, pp. 241-280.
Corapcioglu, M.O., Huang, C.P., 1987. The surface acidity and characterization of some commercial activated carbons. Carbon 25, 569-578.

Fabish, T., Schleifer, D.E., 1984. Surface chemistry and carbon black work function. Carbon 22, 19-38.

Hassler, J.W., 1974. Activated Carbon: Industrial Commercial Environmental. Chemical, New York.

Huang, C.P., 1978. Chemical interactions between inorganic and activated carbon. In: Cheremisinoff, P.N., Ellerbursch, F. (Eds.), Carbon Adsorption Handbook. Ann Arbor Science, New York, pp. 281-330.

Huang, C.P., Stumm, W., 1973. Specific adsorption of cations on hydrous $\mathrm{r}-\mathrm{Al}_{2} \mathrm{O}_{3}$. J. Colloid Interface Sci. 43, 409.

Huang, C.P., 1981. In: Anderson, M.A, Rubin, A.J. (Eds.), The Surface Acidity of Hydrous Solid in Adsorption of Inorganics at Solid-Liquid Interfaces. Ann Arbor Science, New York.

Hunter, R.J., 1987. In: Zeta Potential in Colloid Science, Principles and Applications. Academic Press, San Diego, pp. 11-52.

Magane, P., Dupong-Parlovskky, N., 1988. Graphite-ozone surface complexes. Carbon 26, 249-255.

Mattson, J.S., Mark, H.B., 1971. Activated Carbon: Surface Chemistry and Adsorption from Solution. Marcel Dekker, New York.

Puri, B.R., Bansal, R.C., 1964. Studies in surface chemistry of carbon blacks - II: Surface acidity in relation to chemisorbed oxygen. Carbon 1, 457-464.

Schubert, C.C., Pease, R.N., 1956a. The oxidation of lower paraffin hydrocarbons. II. Observations on the role of ozone in the slow combustion of isobutane. J. Am. Chem. Soc. 78, 5553-5554.

Schubert, C.C., Pease, R.N., 1956b. The oxidation of low paraffin hydrocarbons room temperature reaction of meth- 
ane, propane, $n$-butane and isobutane with ozonized oxygen. Am. Chem. Soc. 78, 2044-2047.

Schubert, C.C., Pease, R.N., 1956c. Reaction of paraffin hydrocarbons with ozonized oxygen: possible role of ozone in normal combustion. J. Chem. Phys. 24, 919923.
Steebberg, B., 1944. Adsorption and Exchange of Ions on Activated Charcoal. Almquist and Wiksells, Uppsala, Sweden. Tryk, D., Aldred, W., Yeager, E., 1984. In: Sarangapani, S., Akridge, J.R., Schumm, B. (Eds.), Proceedings of the Workshop on the Electrochemistry of Carbon. The Electrochemical Society, Pennington, NJ, p. 192. 